\title{
Minat Siswa SMP Terhadap Pembelajaran PJOK Secara Daring Pada Masa New Normal
}

\section{Junior High School Students Interest in Online Physical Education Learning During the New Normal Period}

\author{
Ririn Purnama Dewi ${ }^{1}$, Sepriadi ${ }^{2}$ \\ 1,2 Prodi Pendidikan Jasmani Kesehatan dan Rekreasi, Fakultas IImu Keolahragaan. Universitas \\ Negeri Padang \\ email: ririnpurnama47@gmail.com¹, sepriadi@fik.unp.ac.id²
}

\section{https://doi.org/10.20884/1.paju.2021.2.2.3988}

\begin{abstract}
Abstrak
Pembelajaran pendidikan jasmani mengalami perubahan selama periode pandemi Covid 19 dan pada masa New Normal, sehingga menjadi penting untuk mengetahui minat siswa dalam mengikuti pembelajaran pendidikan jasmani pada masa New Normal Covid 19. Penelitian ini bertujuan untuk mengetahui bagaimana minat siswa terhadap pembelajaran Pendidikan Jasmani Olahraga dan Kesehatan pada Masa New Normal. Jenis penelitian ini digolongkan pada penelitian deskriptif kuantitatif. Metode yang digunakan dalam penelitian ini yaitu dengan menggunakan angket yang diberikan kepada siswa, dari beberapa pernyataan yang akan diisi oleh siswa. Populasi dalam penelitian ini adalah siswa kelas VIII Sekolah Menengah Pertama Negeri 29 Padang yang terdiri dari 264 orang. Sampel dalam penelitian diambil sebanyak 15\% dari setiap kelas dan memakai teknik purposive sampling sehingga sampel berjumlah 40 orang siswa. Untuk mengukur variabel minat siswa maka digunakan instrumen penelitian berupa angket, sedangkan analisis data pada penelitian ini menggunakan teknik analisis deskriptif persentase. Hasil penelitian ini mengkungkapkan bahwa Minat siswa terhadap pembelajaran Pendidikan Jasmani Olahraga dan Kesehatan secara daring pada masa New Normal di Sekolah Menengah Pertama Negeri 29 Padang termasuk ke dalam klasifikasi baik dengan persentase minat belajar $76 \%$. Jadi dapat disimpulkan bahwa minat siswa dalam penelitian ini berada dalam kategori baik.
\end{abstract}

Kata Kunci : Minat siswa, New Normal, Pembelajaran PJOK

\footnotetext{
Abstract

Physical education learning has changed during the Covid 19 pandemic period and during the new normal period, so it is important to know students' interest in taking physical education learning during the new normal Covid 19 period. This study aims to determine how interested students are in learning Physical Education, Sports and Health during the New Normal Period. This type of research is classified in quantitative descriptive research. The method used in this research is to use a questionnaire given to students, from several statements that will be filled in by students. The population in this study were Alamat Koresponden : Prodi Pendidikan Jasmani, Kesehatan dan Rekreasi, Fakultas IImu Keolahragaan. Universitas Negeri Padang

Email : ririnpurnama47@gmail.com (c) (7) 
students of class VIII Junior High School 29 Padang which consisted of 264 people. The sample in the study was taken as much as $15 \%$ from each class and used a purposive sampling technique so that the sample amounted to 40 students. To measure the student interest variable, a research instrument was used in the form of a questionnaire, while the data analysis in this study used a percentage descriptive analysis technique. The results of this study revealed that students' interest in learning physical education, sports and health online during the New Normal period at 29 Padang Public Junior High School was included in the good classification with the percentage of interest in learning $76 \%$. So it can be concluded that the students' interest in this study was in a good category.

Keywords : Student Interest, New Normal, Physical Education Learning

\section{PENDAHULUAN}

Indonesia sedang dilanda wabah virus corona seperti negara-negara lainnya. Virus corona adalah virus yang menyerang sistem pernapasan. Akibatnya semua kegiatan belajar mengajar di sekolah diliburkan, sehingga semua siswa diharuskan untuk belajar di rumah sesuai dengan surat edaran yang dikeluarkan pemerintah pada 18 Maret 2020. Menteri Nadiem Anwar Makarim menerbitkan Surat Edaran Nomor 3 Tahun 2020 pada Satuan Pendidikan dan Nomor 36962/MPK.A/HK/2020 tentang Pelaksanaan Pendidikan dalam Masa Darurat Corona Virus Disease (Covid-19) maka semua kegiatan belajar mengajar di sekolah dilakukan secara DARING (Dalam jaringan) dalam rangka pencegahan penyebaran virus corona (Komarudin \& Prabowo, 2020). Selain itu melakukan social distancing adalah salah satu upaya yang baik untuk pencegahan penyebaran Covid19 (Sadikin \& Hamidah, 2020).Pembelajaran online di masa pandemi adalah bagian dari upaya meningkatkan kewaspadaan terhadap penyebaran virus Covid-19 (Herlina \& Suherman, 2020).

Berdasarkan penjelasan diatas dapat disimpulkan bahwa di masa pandemi ini strategi belajar mengajar yang di gunakan yaitu menggunakan sistem daring. Strategi tersebut merupakan sebuah cara untuk memutus mata rantai penyebaran Covid-19 di masa pandemi. Dengan strategi pembelajaran yang digunakan sekarang yaitu menggunakan sistem daring dengan media internet dan aplikasi lainnya. Sistem pembelajaran daring merupakan sistem dengan pembelajaran tanpa tatap muka secara langsung antara guru dan siswa, tetapi dilakukan melalui online yang menggunakan jaringan internet. Guru harus memastikan kegiatan belajar mengajar tetap berjalan, 
Ririn Purnama Dewi \& Sepriadi | Minat Siswa SMP Terhadap Pembelajaran PJOK Secara Daring Pada Masa New Normal

meskipun siswa berada di rumah. Solusinya, guru dituntut dapat mendesain media pembelajaran sebagai inovasi dengan memanfaatkan media daring.

Dunia pendidikan di Indonesia menghadapi permasalahan yang cukup rumit ditengah pandemi Covid-19 dalam penyelenggaraan pendidikan dan pembelajaran di sekolah. Pada kegiatan belajar mengajar kondisi paling berat dialami oleh sekolah yaitu yang berada jauh dari perkotaan dengan akses internet yang susah untuk didapat dan sarana prasanara yang terbatas. Kegiatan belajar mengajar secara daring dimasa new normal yang belum bisa dilakukan secara tatap muka. Pembelajaran online merupakan bentuk pembelajaran/pelatihan jarak jauh dengan memanfaatkan teknologi telekomunikasi dan informasi, misalnya internet, $C D-R O O M$ (secara langsung dan tidak langsung). Pembelajaran online menghubungkan pembelajar (peserta didik) dengan sumber belajarnya (data base, pakar/instruktur, perpustakaan) yang secara fisik terpisah atau bahkan berjauhan namun dapat saling berkomunikasi, berinteraksi atau berkolaborasi (secara langsung/synchronous dan secara tidak langsung/asynchronous) (Rosali, 2020).

Pendidikan sangat penting diberikan sejak kecil. Pendidikan dapat diterima dari mana saja yaitu, pendidikan yang diberikan dari orang tua, pendidikan yang diberikan di sekolah, bahkan pendidikan juga dapat diperoleh dari lingkungan sekitar. Pendidikan adalah faktor utama dalam meningkatkan kualitas SDM di dunia. Oleh karena itu pendidikan harus berkontribusi untuk visi baru tentang pembangunan global secara baik dan berkelanjuutan (Mustafa \& Dwiyogo, 2020). Menurut UU No.20 tahun 2003 tentang sistem pendidikan Nasional Pasal 1 Ayat 1 yang berbunyi sebagai, Pendidikan adalah usaha sadar untuk mewujudkan agar peserta didik, secara aktif mengembangkan potensi dirinya untuk memiliki kekuatan spiritual keagamaan, pengendalian diri, kepribadian, kecerdasan, akhlak mulia, serta ketrampilan yang diperoleh dirinya, masyarakat, bangsa dan negara.

Pendidikan sangat dibutuhkan sejak dari duduk dibangku TK sampai tingkat perguruan tinggi untuk mendukung tercapainya tujuan pendidikan nasional. Keberhasilan penyelenggara pendidikan suatu negara dapat dilihat dari sejauh mana tujuan pendidikan tersebut terealisasi. Namun pada dasarnya keberhasilan pendidikan tidak hanya tanggung jawab dari pemerintah saja tapi juga dibutuhkan usaha dari siswa itu sendiri.

Dari kutipan di atas dapat diketahui bahwa pencapaian tujuan pendidikan yang demikian sempurna ini, membutuhkan peran serta yang baik dari penyelenggaraan 
pendidikan, subjek pendidikan (guru) objek pendidik (siswa) serta komponen-komponen yang dimaksud antara lain adalah guru yang profesional, murid, keberhasilan, pengolahan administrasi, teknologi intruksional, media pendidikan, biaya, sarana dan prasarana, tanggung jawab keluarga dan partisipasi masyarakat.

Dalam proses pembelajaran, minat merupakan salah satu motivasi dari dalam diripeserta didik sebagai awal penggerakan untuk siswa dalam belajar yang dapat digunakan untuk mencapai tujuan yang diingkinkan. Hal ini menggambarkan bahwa peserta didik yang memiliki minat belajar dalam dirinya maka dia akan semangat dalam mengikuti kegiatan pembelajran dan mencapai keinginan atau cita-citanya, tetapi jika peserta didik tidak memiliki minat dalam belajar maka peserta didik tersebut tidak akan bisa mencapai keinginan atau cita-citanya. Minat belajar siswa sangat dibutuhkan dalam pemebelajaran, agar siswa tersebut mempunyai ketertarikan terhadap materi yang diajarkan. Selain minat peserta diidk juga membutuhkan dorongan atau penggerak untuk mencapai tujuannya atau cita-citanya (Fauziah et al., 2017). Minat adalah suatu pemusatan perhatian yang tidak sengaja yang terlahir dengan melalui partisipasi dalam suatu aktivitas karena minat bersikap khusus tanpa adanya paksaan dari orang lain (Saleh \& Malinta, 2020). Pendapat lain menyatakan bahwa minat belajar merupakan kecenderungan individu dalam memiliki rasa senang dan doronngan dalam mengikuti kegiatan belajar mengajar di sekolah melalui berbagai aktivitas dan pengelaman yang diberikan oleh guru (Tengah, 2020).

Minat peserta didik terhadap pembelajaran khususnya pada pembelajaran Pendidikan Jasmani Olahraga dan Kesehatan terbagi menjadi dua yaitu internal dan eksternal. Dapat disimpulkan juga dengan keadaan sekarang pembelajaran secara daring di masa new normal, dimana minat siswa terhadap pembelajaran itu dapat di pengaruhi dari dalam dan dari luar. Jika dilihat dari dalam diri atau internal peserta didik itu tergantung dari siswa itu sendiri bagaimana dia menilai sesuatu pembelajaran itu akan bermanfaat atau tidak, jika bagi dirinya kegiatan tersebut bermanfaat maka bisa di katakan siswa tersebut berminat dan jika dari dirinya tidak berminat maka siswa tersebut tidak akan serius untuk mengikuti pembelajaran. Sedangkan jika di lihat dari luar atau eksternal yang mempengaruhi minat belajar peserta didik itu sendiri berasal dari pendidik/guru, keluarga, teman serta orang terdekat lainnya. Hal ini di karenakan peserta didik tersebut sangat membutukan masukan, motivasi dan semangat dari guru, keluarga, teman dan orang 
Ririn Purnama Dewi \& Sepriadi | Minat Siswa SMP Terhadap Pembelajaran PJOK Secara Daring Pada Masa New Normal

terdekat lainnya. Karena semua hal tersebuat sangat mempengaruhi minat siswa dalam pembelajaran terutama terhadap pembelajaran Pendidikan Jasmani Olahraga dan Kesehatan.

Minat Siswa Kelas VIII Terhadap Pembelajaran PJOK secara daring di Sekolah Menengah Pertama Negeri 29 Padang bisa dilihat dari bagaimana siswa tersebut mengikuti kegiatan pembelajaran. Setelah peneliti melakukan observasi, kegiatan pembelajaran Pendidikan Jasmani Olahraga dan Kesehatan secara daring di masa new normal bisa di lihat bahwa siswa kurang berperan aktif terhadap kegiatan pembelajaran, melaikan orang tua yang lebih berperan aktif. Hal ini terlihat pada saat siswa mengikuti pembelajaran daring, kehadiran seerta keterlibatan siswa dalam proses pembelajaran menjadi terbatas dan cenderung pasif. Selain itu, pada saat siswa mengerjakan tugas dari guru, tugas tersebut sebagain besar dikerjakan oleh orang tua siswa.

Jika siswa tersebut mengikuti pembelajaran dengan baik maka minatnya dalam mengikuti pembelajaran bisa dikatakan cukup tinggi, begitu juga sebaliknya jika siswa yang tidak mengikuti pembelajaran dengan baik maka bisa di katakan minat dalam pembelajaran Pendidikan Jasmani Olahraga dan Kesehatannya kurang. Minat belajar siswa yang kurang secara daring, dapat ditandai dengan adanya, siswa yang menunjukkan sikap yang tidak serius, main-main, kurangnya rasa ingin berlatih terhadap materi pembelajaran yang diajarkan secara daring, mereka cenderung memperoleh hasil belajar yang kurang memuaskan dikarenakan terkendala oleh keterbatasan media, jaringan internet, sarana prasarana yang kurang memadai, dan kurangnya kepercayaan diri dari siswa tersebut untuk melakukan interaksi secara langsung kepada guru, sehingga dalam pembelajaran daring peran orang tua sangat di butuhkan, bisa dikatan orang tua lebih berperan penting dalam kegiatan pembelajaran daring.

Berdasarkan teori dan permasalahan di lapangan, maka tujuan dari penelitian ini yaitu ingin mengkaji mengenai minat siswa SMP dalam pelasanaan pembelajaran daring pada mata pelajaran PJOK di massa new normal Covid 19.

\section{METODE}

Jenis penelitian ini merupakan penelitian deskriptif kuantitatif tidak melakukan manipulasi atau memberikan perlakuan-perlakuan tertentu terhadap variabel atau merancang sesuatu yang diharapkan terjadi pada variabel, tetapi semua kegiatan, 
keadaan, kejadian, aspek, komponen atau variabel berjalan sebagaimana adanya dan hasil akhir berupa angka-angka (Depiyanti, 2014).

Teknik pengumpulan data dalam penelitian ini berbentuk angket yaitu suatu cara pengumpulan data dengan menyusun daftar pertanyaan atau pernyataan yang diberikan kepada orang lain untuk bersedia memberikan respon sesuai permintaan. Tempat Penelitian ini dilaksanakan di Sekolah Menengah Pertama Negeri 29 Padang, tepatnya di Jl. Kurao Padang, Kec. Nanggalo, Kota Padang, Sumatera Barat, dilakukan secara online. Waktu penelitian ini dilaksanakan pada bulan Desember 2020. Teknik pengumpulan data dalam penelitian ini berbentuk angket atau kuesioner, yaitu metode pengumpulan data berupa sejumlah pertanyaan dan pernyataan tertulis yang dibagikan kepada responden. Tujuannya untuk memperoleh informasi dari responden tentang apa yang siswa alami dan ketahui (Siyoto, Sandu \& Sodik, 2015).

\section{HASIL}

Hasil penelitian mengenai minat siswa SMPN 29 Padang dalam mengikuti pembelajaran PJKO secara daring pada masa New Normal dapat dilihat pada tabel 1. dibawah ini.

Tabel 1. Distribusi Frekuensi Data Minat Belajar Siswa

\begin{tabular}{ccccc}
\hline NO & Kelas Interval & Kalasifiksi & Fa & Fr(\%) \\
\hline 1 & $81-100$ & Sangat Baik & 15 & $37,5 \%$ \\
\hline 2 & $61-80$ & Baik & 25 & $62,5 \%$ \\
\hline 3 & $41-60$ & Cukup & 0 & $0 \%$ \\
\hline 4 & $21-40$ & Kurang & 0 & $0 \%$ \\
\hline 5 & $0-20$ & Kurang Sekali & 0 & $0 \%$ \\
\hline & $\boldsymbol{\Sigma}$ & & 40 & $100 \%$ \\
\hline
\end{tabular}

Berdasarkan tabel diatas, diketahui bahwa dari 40 orang peserta didik, dengan mengajukan 44 pernyataan yang berhubungan dengan minat siswa kelas VIII terhadap pembelajaran PJOK, yaitu jumlah peserta didik yang berada di kalsifikasi "sangat baik" dalam minat belajar berjumlah 15 orang, jumlah siswa yang berada di kalsifikasi "baik" dalam minat belajar berjumlah 25 orang, sedangkan untuk klasifikasi cukup, kurang, dan kurang sekali tidak ada. Dengan demikian diperoleh tingkat capaian minat siswa Kelas VIII 
Ririn Purnama Dewi \& Sepriadi | Minat Siswa SMP Terhadap Pembelajaran PJOK Secara Daring Pada Masa New Normal

terhadap pembelajaran PJOK secara daring pada masa New Normal di Sekolah Menengah Pertama Negeri 29 Padang sebesar 62,5\% dalam kategori baik.

\section{PEMBAHASAN}

Berdasarkan hasil penelitian tentang minat sswa kelas VIII Terhadap pembelajaran PJOK secara daring pada masa New Normal di Sekolah Menengah Pertama Negeri 29 Padang, diperoleh tingkat capaian sebesar $62,5 \%$ dan berada pada kategori minat siswanya "Baik". Artinya minat belajar siswa baik dalam mengikuti mata pelajaran Pendidikan Jasmani Olahraga dan kesehatan. Sesuai dengan temuan tersebut dapat dikatakan bahwa siswa yang terpilih sebagai sampel dalam penelitian ini memiliki minat yang baik dalam mengikuti mata pelajaran Pendidikan Jasmani Olahraga dan Kesehatan. Hal ini terlihat dari hasil penelitian penulis bahwa siswa tersebut mengikuti mata pelajaran Pendidikan Jasmani Olahraga dan kesehatan dengan baik. Pembelajaran daring dimana pembelajarannya menggunakan dengan bantuan jaringan internet (online) sehingga akan terjadi interaksi belajar mengajar antara guru dan siswa dengan memanfaatkan teknologi informasi secara virtual (Nurrohim, 2020).

Di era saat ini dimana perkembangan teknologi yang semakin canggih dengan berbagai aplikasi dan fitur yang semakin memudahkan pengguna. Tidak terikatnya waktu dan dapat dilakukan tanpa harus bertatap muka menjadi keunggulan tersendiri pada pembelajaran daring yang dapat dimanfaatkan dalam dunia pendidikan ditengah masa pandemi Covid-19. Pandemi Covid-19 ini berdampak besar pada semua bidang termasuk pada bidang pendidikan. Akibat pandemi Covid-19, sekolah ditutup, siswa dituntut untuk belajar dari rumah sebab peerintah menerbitkan aturan social distancing untuk semua lapisan masyarakat.

Minat adalah sesuatu yang sangat penting bagi seseorang dalam melakukan kegiatan dengan baik. Sebagai suatu aspek kejiwaan, minat bukan saja dapat mempengaruhi perilaku seseorang, tetapi lebih dari itu minat mendorong orang untuk melakukan suatu kegiatan dan menyebabkan seseorang menaruh perhatian dan merelakan dirinya untuk terikat pada suatu kegaitan (Rahmayanti, 2016). Minat belajar adalah kecenderungan hati peserta didik untuk melakukan suatu kegiatan (belajar) tanpa disertai adanya paksaan dari luar individu (Kelas et al., 2020). Dengan demikian, maka siswa kelas VIII di Sekolah Menengah Pertama 29 Padang memiliki minat dalam mengikuti 
mata pelajaran tersebut, sehingga kegiatan pembelajaran PJOK secara daring dapat terlaksana secara baik.

Pendidikan Jasmani, olahraga dan kesehatan merupakan media untuk mendorong pertumbuhan fisik, perkembangan psikis, keterampilan motorik, pengetahuan dan penalaran, penghayatan nilai-nilai sikap serta kebiasaan pola hidup sehat yang bermuara untuk meransang pertumbuhan dan perkembangan kualitas fisik dan psikis yang seimbang dalam bentuk pendidikan (Afrinal, 2019).

Dalam mengikuti pembelajaran PJOK sangat dibutuhkan adanya konsistensi dengan rasa senang. Rasa senang dalam mengikuti aktivitas pembelajaran tersebut nantinya akan memunculkan kecendrungan untuk menetapkan diri dalam belajar. Hal ini yang dinamakan dengan minat terhadap pembelajaran Pendidikan Jasmani. Rasa senang seseorang tergantung dari rasa suka dan tidak suka terhadap yang mereka lihat dan apa yang mereka lakukan. Terkadang siswa kelas VIII di Sekolah Menengah Pertama 29 Padang, takut dan malas mengikuti kegiatan pembelajaran sekarang yang dilakukan secara daring, dengan demikian tidak akan tercapai tujuan pembelajaran yang di harapkan dalam pemebelajaran PJOK.

Dimasa sekarang semua kegiatan pembelajaran dilakukan secara daring, dimana yang lebih berperan aktif itu orang tua atau wali murid dibandingkan dengan siswa itu sendiri. Dilihat dari kegiatan pembelajaran yang telah dilakukan, seharusnya siswa yang harus lebih berperan aktif agar tujuan dan kegiatan bisa tercapai dengan baik. Ada beberapa faktor yang mempengaruhi minat belajar peserta diidik yaitu faktor internal dan ekstenal, diantaranya yang menjadi indikator untuk mengukur minat belajar siswa dalam penelitian ini yaitu meliputi perhatian, rasa senang, ketertarikan, keterlibatan, guru, keluarga dan lingkungan. Pendapat lain mengatakan faktor-faktor yang mempengaruhi minat belajar adalah 1) Memotivasi dan Cita-cita, 2) keluarga, 3) peranan guru, 4) sarana dan pra sarana, 5) teman pergaulan dan 6)media social (Simbolon, 2014).

Berdasarkan penjelasan di atas, dapat kita lihat terdapat banyak faktor yang mempengaruhi minat belajar pada diri siswa. Salah satu yang mempengarhui minat belajar adalah guru. Guru sebagai fasilitator pembelajaran, guru menciptakan bagaimana kegiatan pembelajaran berlangsung dengan baik atau tidaknya dan memberikan kemudahan bagi siswa untuk belajar. Guru memahami karakteristik dan berupaya memenuhi kebutuhan 
Ririn Purnama Dewi \& Sepriadi | Minat Siswa SMP Terhadap Pembelajaran PJOK Secara Daring Pada Masa New Normal

pendidikan yang bersifat khusus dari masing-masing peserta didik yang memiliki minat dan potensi yang perlu di wujudkan secara optimal.

Ketika berlangsungnya kegiatan belajar mengajar yang perlu diketahui adalah orientasi pembelajaran harus disesuaikan dengan perkembangan siswa, dalam penyampaian materi guru harus mengetahui perkembangan siswa agar materi yang disampaikan oleh guru kepada siswa dapat dimengerti dengan mudah sehingga proses pembelajaran menarik dan menyenangkan bagi siswa. Tujuan pembelajaran bukan hanya ditujukan untuk mengembangkan pengetahuan, tetapi juga untuk membangun keterampilan siswa seutuhnya. Dalam proses pembelajaran di sekolah siswa akan cenderung menyukai salah satu mata pelajaran, salah satunya yaitu mata pelajaran PJOK.

Melihat penelitian penulis pada 40 orang siswa kelas VIII Sekolah Menengah Pertama Negeri 29 Padang yang dilakukan secara online, minat siswa sudah baik dengan tingkat capaian $76 \%$, dan berada pada kategori "Baik" sesuai dengan kalasifikasinya dalam rentang 60\%- 80\%. Artinya minat siswa kelas VIII terhadap pembelajaran PJOK secara daring pada masa New Normal di Sekolah Menengah Pertama Negeri 29 Padang baik dalam pelaksanaannya.

Jadi untuk mencapai hal yang lebih baik dalam menimbulkan rasa senang siswa kelas VIII Sekolah Menengah Pertama 29 Padang itu tergantung dari diri siswa itu sendiri. Dan dapat ditingkatkan lagi oleh guru PJOK dengan cara memberikan motivasi dan dorongan terhadap siswa dalam mengikuti mata pelajaran PJOK. Serta bagaimana orang tua dan keluarga membimbing dan mengarahkan agar anak atau siswa tersebut memiliki minat untuk mengikuti kegiatan pembelajaran.

\section{SIMPULAN}

Berdasarkan hasil penelitian, dengan tujuan peneliti ingin mengetahui bagaimana tingkat minat siswa terhadap pembelajaran PJOK secara daring pada masa New Normal di Sekolah Menengah Pertama Negeri 29 Padang maka dapat diambil simpulan sebagai berikut: Tingkat minat siswa kelas VIII terhadap pembelajaran PJOK secara daring pada masa New Normal berada dalam kategori baik. Rekomendasi untuk penelitian selanjutnya dapat melakukan survey minat pembelajaran PJOK pada siswa SMA, atau dapat dilakukan penelitian mengenai dampak dari proses pembelajaran PJKO secara daring pada aspek kognitif, psikomotor maupun aspek afektif lainnya. 


\section{REFERENSI}

Adhe Afrinal, A. U. (2019). Tinjauan Pelaksanaan Pembelajaran PJOK di SD Gugus III Kec.koto VII Kab.Sijunjung. Jurnal Pendidikan Dan Olahraga, 2(1), 188-191.

Depiyanti, O. M. (2014). Model Pendidikan Karakter di Islamic Full Day School (Studi Deskriptif pada SD Cendekia Leadership School, Bandung). TARBAWY: Indonesian Journal of Islamic Education, 1(2), 132. https://doi.org/10.17509/t.v1i2.3769

Fauziah, A., Rosnaningsih, A., \& Azhar, S. (2017). Hubungan Antara Motivasi Belajar Dengan Minat Belajar Siswa Kelas Iv Sdn Poris Gaga 05 Kota Tangerang. Jurnal JPSD (Jurnal Pendidikan Sekolah Dasar), 4(1), 47. https://doi.org/10.26555/jpsd.v4i1.a9594

Herlina, H., \& Suherman, M. (2020). Potensi Pembelajaran Pendidikan Jasmani Olahraga Dan Kesehatan (Pjok) Di Tengah Pandemi Corona Virus Disease (Covid)-19 Di Sekolah Dasar. Tadulako Journal Sport Sciences And Physical Education, 8(1), 17. http://jurnal.untad.ac.id/jurnal/index.php/PJKR/article/view/16186

Kelas, P., Universitas, F., \& Oleo, H. (2020). Kata Kunci: Minat Belajar, Hasil Belajar, Evaluasi Pembelajaran Penjas. 27, 25-33.

Komarudin, \& Prabowo, M. (2020). Persepsi Siswa Terhadap Pembelajaran Daring Mata Pelajaran Pendidikan Jasmani Olahraga Dan Kesehatan Pada Masa Pandemi Covid-19. Majalah IImiah Olahraga (MAJORA), 26(2), 56-66.

Mustafa, P. S., \& Dwiyogo, W. D. (2020). Kurikulum Pendidikan Jasmani, Olahraga, dan Kesehatan di Indonesia Abad 21. JARTIKA Jurnal Riset Teknologi Dan Inovasi Pendidikan, 3(2), 422-438. https://doi.org/10.36765/jartika.v3i2.268

Nurrohim, N. (2020). Analisis Kepuasan Siswa Kelas IX Sekolah Menengah Pertama Terhadap Pembelajaran Daring Mata Pelajaran PJOK Pada Masa Pandemi Covid19 Kecamatan Purwanegara 2020. Journal of Physical Activity and Sports, 1(1), 133-146.

Rahmayanti, V. (2016). Pengaruh Minat Belajar Siswa dan Persepsi atas Upaya Guru dalam Memotivasi Belajar Siswa terhadap Prestasi Belajar Bahasa Indonesia Siswa SMP di Depok. SAP (Susunan Artikel Pendidikan), 1(2), 206-216. https://doi.org/10.30998/sap.v1i2.1027

Rosali, E. S. (2020). Aktifitas Pembelajaran Daring Pada Masa Pandemi Covid -19 Di. Geography Science Education Journal (GEOSEE), 1(1), 21-30. https://www.researchgate.net/publication/340917125_Kendala_Pelaksanaan_Pem belajaran_Jarak_Jauh_PJJ_dalam_Masa_Pandemi/stats

Sadikin, A., \& Hamidah, A. (2020). Pembelajaran Daring di Tengah Wabah Covid-19. Biodik, 6(2), 109-119. https://doi.org/10.22437/bio.v6i2.9759 
Ririn Purnama Dewi \& Sepriadi | Minat Siswa SMP Terhadap Pembelajaran PJOK Secara Daring Pada Masa New Normal

Saleh, M. S., \& Malinta, S. S. (2020). Survei Minat Belajar Siswa Dalam Mengikuti Pembelajaran Pendidikan Jasmani Di Smpn 30 Makassar. Kinestetik, 4(1), 55-62. https://doi.org/10.33369/jk.v4i1.10347

Simbolon, N. (2014). Faktor Faktor Yang Mempengaruhi Minat Belajar Peserta Didik. Elementary School Journal Pgsd Fip Unimed, 1(2), 14-19.

Siyoto, Sandu \& Sodik, M. A. (2015). Dasar Metode Penelitian. Literasi Media Publishing.

Tengah, L. (2020). Hubungan Minat Belajar Ipa Siswa Kelas V Sd Negeri 2 Pelemkerep Terhadap Hasil Belajar Selama Pembelajaran Daring. Progres Pendidikan, 1(September), 72-79. 